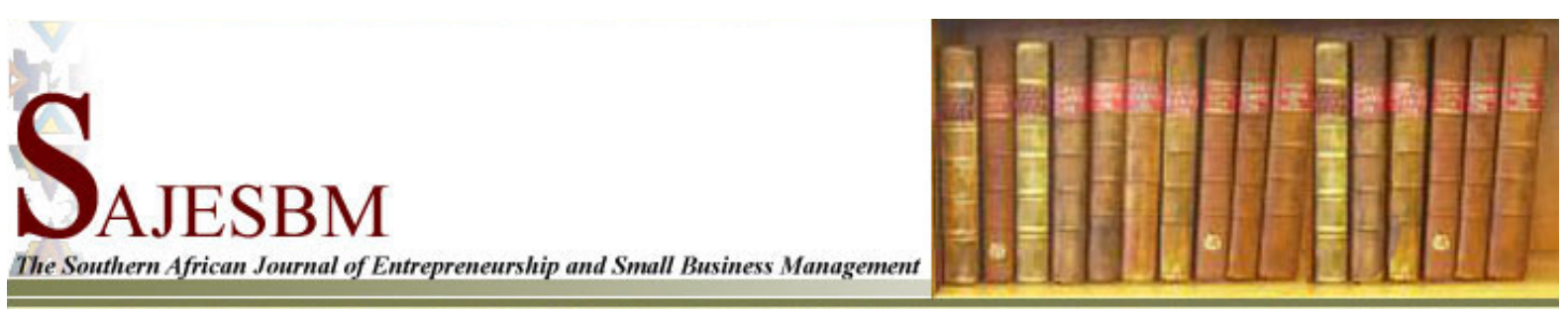

\title{
ENTREPRENEURIAL INTENTIONS AND BEHAVIOURS OF SOUTH AFRICAN UNIVERSITY STUDENTS
}

\author{
Dr Suzette Viviers \\ Senior lecturer, Department of Business Management, Stellenbosch University \\ Mr Goosain Solomon* \\ Lecturer, Department of Business Management, Stellenbosch University \\ Ms Chanel Venter \\ Lecturer, Department of Business Management, Stellenbosch University
}

\author{
* Corresponding author \\ Department of Business Management \\ Stellenbosch University \\ Private Bag X1 \\ Matieland, Stellenbosch \\ 7602 \\ South Africa \\ T: 0218082475 \\ F: 0218082226 \\ E: gsolomon@sun.ac.za
}

\begin{abstract}
The entrepreneurial intentions and behaviours of South African university students are important factors to consider when developing entrepreneurship offerings at local universities. This article reports on pertinent findings from a study which set out to determine South African students' career choice intentions and entrepreneurship behaviours as well as their knowledge and utilisation of, demand for and satisfaction with entrepreneurship offerings of local universities relative to international universities. A survey, using a 15question structured web-based instrument was used to capture the responses from university students across 26 nations in the Global University Entrepreneurial Spirit Students' Survey (GUESSS) conducted in 2011. Key findings are that few South Africa university students intend to enter into an entrepreneurship career immediately after completion of their studies, whereas close to a third of respondents were interested in doing so five years after graduation. The vast majority of students were satisfied with entrepreneurship offerings at South African universities. More physical support such as network access platforms are however needed as well as awareness of and access to small business funding mechanisms. Better marketed and focussed entrepreneurship offerings are essential to foster an environment at South African universities to promote entrepreneurship as career choice.
\end{abstract}


Keywords: Entrepreneurial intentions, Entrepreneurial behaviours, Global financial crisis, South African university students

\section{INTRODUCTION AND PROBLEM STATEMENT}

In the light of the role that entrepreneurship plays globally in terms of social and economic enhancement, the third Global University Entrepreneurial Spirit Students' Survey (GUESSS) was undertaken in 2011. The survey set out to measure the entrepreneurial intentions and behaviours of university students in 26 countries, including South Africa. This article focuses exclusively on the responses of 697 South African university students to they survey.

Universities play an important role in fostering entrepreneurship since they are strongly associated with the creation of opportunity-based enterprises (Autio 2005). A better understanding of the factors influencing entrepreneurship offerings at universities will assist educators in designing strategies to stimulate entrepreneurial intentions and behaviours. This article pays particular attention to the empirical findings of the 2011 GUESSS, more specifically to:

- South African students' knowledge of entrepreneurship offerings at their respective universities, their demand for and utilisation of these offerings, and their level of satisfaction with these offerings;

- the career choice intentions of university students giving particular attention to changes that might have occurred as a result of the global financial crisis;

- the entrepreneurial behaviours of South African students; and

- South Africa's entrepreneurial index value.

\section{RESEARCH DESIGN AND METHODOLOGY}

The objectives of this study called for the use of a cross-sectional survey. Details on the questionnaire design, sample selection as well as the methods used to collect and analyse primary data are presented next.

\section{Questionnaire design}

In 2003, researchers at the Swiss Research Institute of Small Business and Entrepreneurship at the University of St. Gallen and the KfW Endowed Chair for Entrepreneurship at the European Business School in Germany designed the first GUESSS questionnaire. They developed a set of 15 questions to measure entrepreneurial intentions and behaviours among university students. By using the same questions, scales, methods and constructs across countries and universities, tangible comparisons of tendencies and trends can be made over time.

\section{Sampling}

Twenty-six countries participated in the survey, with a final sample of 93265 . The South African sample $(N=697)$ was drawn from 15 universities. The 2011 survey was marketed to approximately 13800 students at these universities by making announcements during lectures, placing advertisements on websites, sending e-mails to students, and displaying posters on university campuses. Although the sample was not necessarily representative of the overall student population in South Africa, the study did, however, provide valuable insights into South African students' entrepreneurial intentions and behaviours.

Most of the respondents studied at four universities, namely Stellenbosch University $(44.8 \%)$, North-West University (14.9\%), the University of Pretoria (10.8\%) and the Nelson Mandela Metropolitan University (10.5\%). The remaining respondents (19.4\%) came from the other eleven universities. 


\section{Data collection and analysis}

The survey was administered by means of a web-based questionnaire. The raw data were processed by the project coordinators in Switzerland, and datasets were distributed to representatives in each participating country. Descriptive statistics based on 697 questionnaires were computed using the IBM SPSS Statistics (version 19) software program.

\section{Sample description}

Biographic details of the South African and international university student samples are presented in Table 1.

Table 1 Sample description - biographic details

\begin{tabular}{|c|c|c|}
\hline & $\begin{array}{l}\text { South African students } \\
\qquad \mathrm{N}=697\end{array}$ & $\begin{array}{c}\text { International students } \\
\mathrm{N}=93265\end{array}$ \\
\hline Age & $\%$ & $\%$ \\
\hline Younger than 25 years & 86.9 & 60.6 \\
\hline 25 to 30 years & 8.6 & 25.8 \\
\hline Older than 30 years & 4.3 & 13.6 \\
\hline Total & 100 & 100 \\
\hline \multicolumn{3}{|l|}{ Gender } \\
\hline Male & 44.8 & 54.7 \\
\hline Female & 55.2 & 45.3 \\
\hline Total & 100 & 100 \\
\hline \multicolumn{3}{|l|}{ Home language } \\
\hline Afrikaans & 40.2 & $\mathrm{~N} / \mathrm{A}$ \\
\hline English & 38.7 & $\mathrm{~N} / \mathrm{A}$ \\
\hline Other official South African languages ${ }^{(a)}$ & 15.6 & $\mathrm{~N} / \mathrm{A}$ \\
\hline Other $^{(b)}$ & 5.5 & $\mathrm{~N} / \mathrm{A}$ \\
\hline Total & 100 & 100 \\
\hline $\begin{array}{l}\text { (a) IsiNdebele, IsiXhosa, IsiZulu, Sesot } \\
\text { and Xitsonga } \\
\text { (b) German, French, Chinese, Swahili a }\end{array}$ & $\begin{array}{l}\text { sa Leboa, Sesotho, Sets } \\
\text { Oshiwambo }\end{array}$ & ana, siSwati, Tshivenda \\
\hline
\end{tabular}

South African students were generally younger than their international counterparts and slightly more males participated in the South African survey than females. The predominant home languages of South African participants were English and Afrikaans. Figure 1 illustrates that more South African students were enrolled for undergraduate qualifications than students in the international sample, whereas the opposite was true for postgraduate studies. 


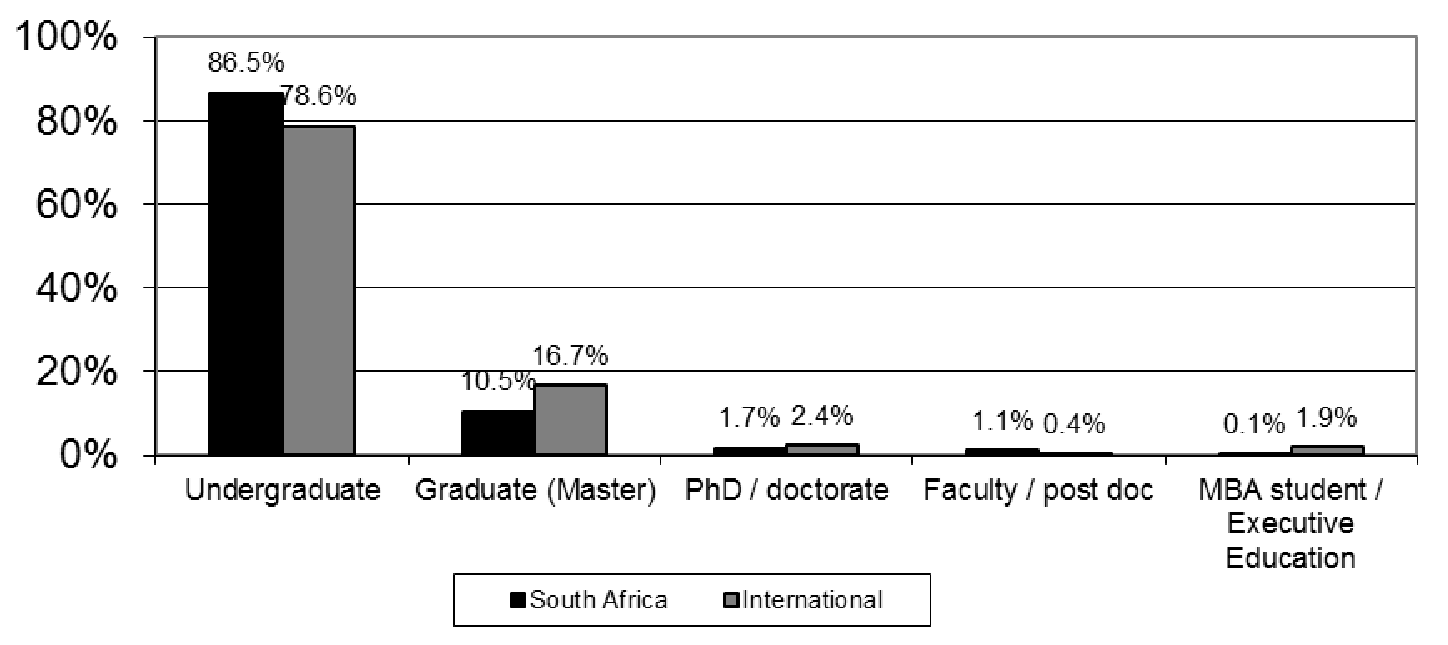

Figure 1: Study level profile of South African and international students

The majority of South African students (71.3\%) were enrolled for qualifications at business and economic sciences faculties, specialising in management/business administration, economics and accounting/financial accounting/internal auditing. Twenty per cent of students studied towards degrees in the natural sciences with the remainder enrolled for qualifications in the social sciences.

Having profiled the sample, the focus of this article now turns to students' awareness of, demand for, utilisation of and evaluation of entrepreneurship offerings at their respective universities.

\section{ENTREPRENEURSHIP OFFERINGS AT SOUTH AFRICAN UNIVERSITIES}

Universities play a pivotal role in promoting more and better entrepreneurship. It is therefore important to investigate the nature and quality of entrepreneurship offerings available to students. For the purpose of this paper entrepreneurship offerings were classified into three categories, namely lectures and seminars, workshops and coaching opportunities, and the provision of resources for founders/entrepreneurs.

\section{Students' awareness of university offerings}

Students were requested to indicate their level of awareness of entrepreneurship offerings at their respective universities. The findings are ranked from best known to least known offerings per category in Table 2. 
Table 2 Students' awareness of existing university offerings

\begin{tabular}{|c|c|c|c|c|c|c|c|}
\hline \multirow[t]{2}{*}{ Type of offering } & \multirow[t]{2}{*}{ Item } & \multicolumn{3}{|c|}{$\begin{array}{c}\text { South African } \\
\text { students }(N=697)\end{array}$} & \multicolumn{3}{|c|}{$\begin{array}{c}\text { International } \\
\text { students ( } \mathrm{N}=93 \\
265)\end{array}$} \\
\hline & & $\begin{array}{c}\% \\
\text { Yes }\end{array}$ & $\begin{array}{c}\% \\
\text { No }\end{array}$ & $\begin{array}{c}\% \\
\text { Do not } \\
\text { know }\end{array}$ & $\begin{array}{l}\% \\
\text { Yes }\end{array}$ & $\begin{array}{l}\% \\
\text { No }\end{array}$ & $\begin{array}{c}\% \\
\text { Do not } \\
\text { know }\end{array}$ \\
\hline \multirow{8}{*}{$\begin{array}{l}\text { Lectures and } \\
\text { seminars }\end{array}$} & Entrepreneurship in general & 80.8 & 4.7 & 14.5 & 61.0 & 9.8 & 29.2 \\
\hline & Business planning & 79.5 & 4.6 & 15.9 & 53.8 & 9.9 & 36.3 \\
\hline & Entrepreneurial marketing & 72.2 & 5.9 & 22.0 & 41.4 & 13.5 & 45.2 \\
\hline & Innovation and idea generation & 66.4 & 6.6 & 27.0 & 47.7 & 11.9 & 40.4 \\
\hline & Financing entrepreneurial ventures & 60.5 & 8.3 & 31.1 & 32.2 & 18.8 & 49.1 \\
\hline & Social entrepreneurship & 51.9 & 8.6 & 39.5 & 34.4 & 15.5 & 50.0 \\
\hline & Technology entrepreneurship & 47.5 & 10.5 & 42.0 & 30.8 & 18.5 & 50.7 \\
\hline & Family businesses & 22.2 & 17.1 & 60.7 & 14.9 & 29.2 & 55.9 \\
\hline \multirow{5}{*}{$\begin{array}{l}\text { Workshops and } \\
\text { coaching } \\
\text { opportunities }\end{array}$} & Networking with experienced entrepreneurs & 48.4 & 14.1 & 37.6 & 45.7 & 15.8 & 38.5 \\
\hline & $\begin{array}{l}\text { Mentoring and coaching programmes for } \\
\text { entrepreneurs }\end{array}$ & 48.1 & 12.5 & 39.5 & 25.5 & 19.3 & 55.2 \\
\hline & Business plan contests/workshops & 47.6 & 14.3 & 38.0 & 39.1 & 17.1 & 43.9 \\
\hline & Contact point for entrepreneurial issues & 43.8 & 11.8 & 44.5 & 32.0 & 16.8 & 51.2 \\
\hline & Contact platforms with potential investors & 34.7 & 16.6 & 48.6 & 22.7 & 22.9 & 54.4 \\
\hline \multirow[t]{2}{*}{$\begin{array}{l}\text { Provision of } \\
\text { resources }\end{array}$} & $\begin{array}{llll}\begin{array}{l}\text { Technology and } \\
\text { (library, web) }\end{array} & \text { research resources } \\
\end{array}$ & 92.7 & 1.6 & 5.7 & 74.3 & 5.2 & 20.4 \\
\hline & Seed funding/financial support & 56.0 & 10.2 & 33.9 & 19.4 & 23.6 & 57.0 \\
\hline
\end{tabular}

Table 2 shows that South African students were more aware of entrepreneurship offerings than those in the international sample, with lectures on entrepreneurship in general $(80.8 \%)$ and business planning (79.5\%) being most prominent. It might also be as a result of the bulk of the South African students being commerce students $(71.3 \%)$ compared to the international sample where most students were registered for qualifications in the natural sciences (32.9\%).

Many students, however, reported low levels of awareness in terms of the existence of entrepreneurship offerings. Of interest was the relatively high level of awareness of theoretically based offerings such as general entrepreneurship to the relatively low level of awareness of more practical offerings such as contact points for entrepreneurial issues. This can be understood in the light that most students in the South African sample were commerce students with a high probability of having entrepreneurship as a module.

Table 2 also shows the high level of awareness of the technological and research resources that are available at the students' respective universities, more so in the South African sample than in the international sample. Since universities provide students with state-ofthe-art technological research support, this result could have been expected. This finding was in contrast to that of the 2008/9 GUESSS survey, which revealed relatively low levels of awareness for start-up financing (15.9\%) (Scheepers, Solomon \& De Vries 2009:14). The increase in awareness reported in the present study was rather encouraging in that it suggests higher levels of interest in entrepreneurship. 


\section{The demand for university entrepreneurship offerings}

Respondents were further asked concerning their need for specific entrepreneurship offerings. Table 3 represents the findings ranked in order of most in demand to least in demand for the South African sample.

Table 3 The demand for university entrepreneurship offerings (not currently offered)

\begin{tabular}{|c|c|c|c|c|c|c|c|}
\hline Type of offering & \multirow[b]{2}{*}{ Item } & \multicolumn{3}{|c|}{ South African students } & \multicolumn{3}{|c|}{ International students } \\
\hline & & $\begin{array}{l}\text { Valid } \\
\mathbf{N}\end{array}$ & $\begin{array}{c}\text { Would } \\
\text { like } \\
\%\end{array}$ & $\begin{array}{c}\text { Do } \\
\text { not } \\
\text { need } \\
\%\end{array}$ & $\begin{array}{l}\text { Valid } \\
\text { N }\end{array}$ & $\begin{array}{l}\text { Would } \\
\text { like } \\
\%\end{array}$ & $\begin{array}{c}\text { Do } \\
\text { not } \\
\text { need } \\
\%\end{array}$ \\
\hline \multirow{8}{*}{$\begin{array}{ll}\text { Lectures } & \text { and } \\
\text { seminars } & \end{array}$} & Business planning & 143 & 87.4 & 12.6 & 43107 & 65.6 & 34.4 \\
\hline & Innovation and idea generation & 234 & 85.9 & 14.1 & 48753 & 69.5 & 30.5 \\
\hline & Financing entrepreneurial ventures & 275 & 84.4 & 15.6 & 63257 & 65.3 & 34.7 \\
\hline & Entrepreneurship in general & 134 & 82.8 & 17.2 & 36338 & 64.0 & 36.0 \\
\hline & Entrepreneurial marketing & 194 & 80.4 & 19.6 & 54666 & 52.7 & 47.3 \\
\hline & Technology entrepreneurship & 366 & 73.2 & 26.8 & 64525 & 49.5 & 50.5 \\
\hline & Social entrepreneurship & 335 & 69.3 & 30.7 & 61146 & 54.3 & 45.7 \\
\hline & Family businesses & 542 & 47.0 & 53.0 & 79353 & 42.4 & 57.6 \\
\hline \multirow{5}{*}{$\begin{array}{l}\text { Workshops } \\
\text { coaching } \\
\text { opportunities }\end{array}$} & $\begin{array}{l}\text { Networking with experienced } \\
\text { entrepreneurs }\end{array}$ & 360 & 86.4 & 13.6 & 50654 & 70.7 & 29.3 \\
\hline & $\begin{array}{l}\text { Contact platforms with potential } \\
\text { investors }\end{array}$ & 455 & 84.8 & 15.2 & 72064 & 66.1 & 33.9 \\
\hline & $\begin{array}{l}\text { Mentoring and coaching } \\
\text { programmes for entrepreneurs }\end{array}$ & 362 & 83.7 & 16.3 & 69487 & 64.2 & 35.8 \\
\hline & Business plan contests/workshops & 365 & 80.5 & 19.5 & 56834 & 59.5 & 40.5 \\
\hline & $\begin{array}{l}\text { Contact point for entrepreneurial } \\
\text { issues }\end{array}$ & 392 & 79.3 & 20.7 & 63416 & 67.1 & 32.9 \\
\hline \multirow{2}{*}{$\begin{array}{l}\text { Provision of } \\
\text { resources }\end{array}$} & Seed funding/financial support & 307 & 80.8 & 19.2 & 75158 & 70.6 & 29.4 \\
\hline & $\begin{array}{lcc}\text { Technology and } & \text { research } \\
\text { resources (library, web) } & \\
\end{array}$ & 51 & 74.5 & 25.5 & 23910 & 62.0 & 38.0 \\
\hline
\end{tabular}

As shown in Table 3, a clear demand exists for all entrepreneurship offerings mentioned. Overall, the demand for entrepreneurship offerings was relatively higher among the South African sample than among the international sample. This finding might be attributed to the increased emphasis on entrepreneurship by local government and the media in recent years (The New Growth Path 2011). Understanding the nature of the demand presents an opportunity for South African universities to sharpen the focus of their marketing strategies.

\section{UTILISATION OF UNIVERSITY ENTREPRENEURSHIP OFFERINGS}

The study also examined students' utilisation of existing offerings. Table 4 presents the findings ranked from the most utilised to the least utilised, based on the South African sample.

It is evident from Table 4 that South African students utilised existing entrepreneurship offerings relatively more than their international counterparts. The topics most utilised are the entrepreneurship sensitising topics, namely entrepreneurship in general, business planning, entrepreneurial marketing, and innovation and idea generation. A trend of decreased utilisation as the offerings become more applied and practical was observed, supportive of the notion that the students were keen on entrepreneurship, but deferred active engagement. High utilisation of technological and research resources can be expected at universities as tertiary students are expected to actively engage in research using a variety of state-of-the-art technology and other resources for research. 
Table 4 Utilisation of offerings

\begin{tabular}{|c|c|c|c|c|c|c|c|}
\hline \multirow[t]{2}{*}{$\begin{array}{l}\text { Type of } \\
\text { offering }\end{array}$} & \multirow[t]{2}{*}{ Item } & \multicolumn{3}{|c|}{ South African students } & \multicolumn{3}{|c|}{$\begin{array}{c}\text { International } \\
\text { students }\end{array}$} \\
\hline & & Valid N & $\begin{array}{c}\% \\
\text { Yes }\end{array}$ & $\begin{array}{l}\% \\
\text { No }\end{array}$ & $\underset{N}{\text { Valid }}$ & $\begin{array}{l}\% \\
\text { Yes }\end{array}$ & $\begin{array}{l}\% \\
\text { No }\end{array}$ \\
\hline \multirow{8}{*}{$\begin{array}{l}\text { Lectures and } \\
\text { seminars }\end{array}$} & Entrepreneurship in general & 563 & 71.9 & 28.1 & 56915 & 55.4 & 44.6 \\
\hline & Business planning & 554 & 68.6 & 31.4 & 50146 & 53.1 & 46.1 \\
\hline & Innovation and idea generation & 463 & 67.2 & 32.8 & 44501 & 53.9 & 46.9 \\
\hline & Entrepreneurial marketing & 503 & 61.9 & 38.4 & 38591 & 48.0 & 52.0 \\
\hline & Family businesses & 155 & 58.1 & 41.9 & 13905 & 43.9 & 56.1 \\
\hline & Social entrepreneurship & 362 & 58.0 & 42.0 & 32107 & 45.8 & 54.2 \\
\hline & Financing entrepreneurial ventures & 422 & 57.3 & 42.7 & 29997 & 39.2 & 60.8 \\
\hline & Technology entrepreneurship & 331 & 55.9 & 44.1 & 28730 & 39.5 & 60.5 \\
\hline \multirow{5}{*}{$\begin{array}{l}\text { Workshops } \\
\text { and } \\
\text { coaching } \\
\text { opportunities }\end{array}$} & $\begin{array}{l}\text { Networking with experienced } \\
\text { entrepreneurs }\end{array}$ & 337 & 59.3 & 40.7 & 42601 & 44.1 & 55.9 \\
\hline & $\begin{array}{l}\text { Mentoring and coaching programmes } \\
\text { for entrepreneurs }\end{array}$ & 335 & 51.9 & 48.1 & 23768 & 30.1 & 69.9 \\
\hline & $\begin{array}{l}\text { Contact point for entrepreneurial } \\
\text { issues }\end{array}$ & 305 & 51.1 & 48.9 & 29841 & 37.8 & 62.2 \\
\hline & $\begin{array}{l}\text { Contact platforms with potential } \\
\text { investors }\end{array}$ & 242 & 44.2 & 55.8 & 21192 & 32.9 & 67.1 \\
\hline & Business plan contests /workshops & 332 & 43.7 & 56.3 & 36425 & 34.4 & 65.6 \\
\hline \multirow[t]{2}{*}{$\begin{array}{l}\text { Provision of } \\
\text { resources }\end{array}$} & $\begin{array}{l}\text { Technology and research resources } \\
\text { (library, web) }\end{array}$ & 646 & 86.5 & 13.5 & 69341 & 74.6 & 25.4 \\
\hline & Seed funding/financial support & 390 & 46.2 & 53.8 & 18101 & 41.8 & 58.2 \\
\hline
\end{tabular}

\section{STUDENTS' EVALUATION OF OFFERINGS}

Utilisation of an offering may not necessarily provide a reliable indication of the quality of an offering. Therefore, it was necessary to determine the level of satisfaction with entrepreneurship offerings. The students were asked how satisfied they were with the entrepreneurship offerings they utilised. The responses were captured on a five-point Likertscale with 1 representing 'not at all satisfied' and 5 representing 'very much satisfied'. The findings are presented in Table 5. 
Table 5 Students' level of satisfaction with entrepreneurship offerings

\begin{tabular}{|c|c|c|c|c|c|c|c|}
\hline \multirow[t]{2}{*}{$\begin{array}{l}\text { Students' level of } \\
\text { satisfaction with ... }\end{array}$} & \multirow[t]{2}{*}{ Item } & \multicolumn{3}{|c|}{$\begin{array}{l}\text { South African } \\
\text { students }\end{array}$} & \multicolumn{3}{|c|}{ International students } \\
\hline & & $\underset{\mathbf{N}}{\text { Valid }}$ & Mean & SD & Valid N & Mean & SD \\
\hline \multirow{8}{*}{$\begin{array}{l}\text { lectures and seminars } \\
\text { about ... }\end{array}$} & Business planning & 380 & 3.92 & 0.89 & 26643 & 3.74 & 0.99 \\
\hline & $\begin{array}{l}\text { Innovation and idea } \\
\text { generation }\end{array}$ & 311 & 3.89 & 0.92 & 24005 & 3.77 & 0.99 \\
\hline & $\begin{array}{l}\text { Entrepreneurial } \\
\text { marketing }\end{array}$ & 310 & 3.84 & 0.91 & 18506 & 3.77 & 0.96 \\
\hline & $\begin{array}{l}\text { Entrepreneurship in } \\
\text { general }\end{array}$ & 405 & 3.83 & 0.8 & 31527 & 3.72 & 0.95 \\
\hline & $\begin{array}{l}\text { Social } \\
\text { entrepreneurship }\end{array}$ & 210 & 3.74 & 0.97 & 14709 & 3.71 & 0.97 \\
\hline & $\begin{array}{l}\text { Technology } \\
\text { entrepreneurship }\end{array}$ & 185 & 3.66 & 0.93 & 11348 & 3.68 & 0.97 \\
\hline & Family firms & 90 & 3.64 & 0.93 & 6100 & 3.63 & 1.01 \\
\hline & $\begin{array}{l}\text { Financing } \\
\text { entrepreneurial } \\
\text { ventures }\end{array}$ & 242 & 3.60 & 0.94 & 11745 & 3.61 & 0.99 \\
\hline \multirow[t]{5}{*}{$\begin{array}{l}\text { workshops and coaching } \\
\text { offerings about ... }\end{array}$} & $\begin{array}{l}\text { Business plan } \\
\text { contests / workshops }\end{array}$ & 145 & 3.76 & 0.96 & 12543 & 3.66 & 1.01 \\
\hline & $\begin{array}{l}\text { Mentoring and } \\
\text { coaching } \\
\text { programmes for } \\
\text { entrepreneurs }\end{array}$ & 174 & 3.68 & 0.97 & 7165 & 3.67 & 1.01 \\
\hline & $\begin{array}{l}\text { Networking with } \\
\text { experienced } \\
\text { entrepreneurs }\end{array}$ & 200 & 3.64 & 0.98 & 18768 & 3.70 & 0.99 \\
\hline & $\begin{array}{l}\text { Contact platforms } \\
\text { with potential } \\
\text { investors }\end{array}$ & 107 & 3.57 & 0.98 & 6969 & 3.61 & 1.03 \\
\hline & $\begin{array}{l}\text { Contact point for } \\
\text { entrepreneurial } \\
\text { issues }\end{array}$ & 156 & 3.57 & 0.99 & 11271 & 3.69 & 1.04 \\
\hline \multirow[t]{2}{*}{$\begin{array}{l}\text { provision of resources to } \\
\text { founders/entrepreneurs }\end{array}$} & $\begin{array}{l}\text { Technology and } \\
\text { research resources } \\
\text { (library, web) }\end{array}$ & 559 & 4.24 & 0.83 & 51702 & 3.80 & 1.01 \\
\hline & $\begin{array}{l}\text { Seed funding / } \\
\text { financial support }\end{array}$ & 180 & 3.83 & 1.03 & 7569 & 3.63 & 1.09 \\
\hline
\end{tabular}

The findings suggest that students in both samples seemed to be satisfied with the entrepreneurship offerings at their respective universities. At first glance this finding implies that universities are responding adequately to the needs of students in terms of entrepreneurship offerings. More in-depth research on the topic of entrepreneurship education in South Africa, however, suggests that entrepreneurship programmes, both in terms of content and methods, do not appear to achieve the desired outcomes. Farrington, Gray and Sharp (2001:11) for example call for the integration of different learning experiences into entrepreneurship programmes, such as real world case studies and 'exposure to practice management' in order to provide students with a more realistic perspective of what an entrepreneurial career and business ownership entails. Radipere (2012:11015) also calls for greater use of interactive methods in entrepreneurship education and specifically recommends simulations to allow students to develop analytical and decision-making skills.

Technology and research resources received the highest rating for satisfaction in both samples as well as the highest response rate from all the offerings. This finding was 
indicative of the reliance of the student population on technology, which begs investigation of the impact of the broader university context on the entrepreneurial intentions and behaviours of the respondents.

\section{The university context}

Students were requested to specify their level of agreement with a number of statements concerning the influence that the university context had on their entrepreneurial intentions and behaviours. Their responses were captured on a seven-point Likert-scale, with 1 representing 'strongly disagree' and 7 representing 'strongly agree'.

Based on the mean scores, the three most significant influences reported by the South African students were:

- understanding the actions someone has to take in order to start a business (mean score $=5.13$ );

- identifying an opportunity (mean score $=5.04$ ); and

- understanding the attitudes, values and motivations of entrepreneurs (mean score $=$ 5.00).

Analysis of the three dimensions suggested that the students were seeking firstly to understand the process of starting a business and thereafter to understand the qualities of being entrepreneurial (Frese \& De Kruif 2000:18).

For the international students, the mean scores ranged from 3.67 to 4.28 , suggesting that the international students were fairly indifferent about the effect of the influence the university environment has on their entrepreneurial intentions and behaviours. However, interestingly, the international sample's most significant influence was to understand the attitudes, values and motivations of entrepreneurs (mean score $=4.28$ ), followed by identifying an opportunity (mean score $=4.24$ ), which corresponded to two of the top three influences on the entrepreneurial intentions of the South African sample. The third most significant influencing factor from the university context for the international sample was the ability to develop networks (mean score $=4.15$ ), an influence which the South African sample rated second last (mean score $=4.63$ ).

\section{THE CAREER CHOICE INTENTIONS OF STUDENTS}

According to Barringer and Ireland (2008:15), students enter the labour market immediately after graduation to gain experience and knowledge, and to develop social capital before they pursue longer-term career aspirations. Since the transition to a new democracy in South Africa in 1994, the tendency has been for students to enter a professional career, indicative of a culture that places a premium on professions in the fields such as law, engineering, finance, education and health care. Furthermore, the South African government is encouraging a shift towards a growing knowledge economy by increasing the number of $\mathrm{PhD}$ graduates in order to increase scientific research and development (Republic of South Africa 2008:28).

To gain insight into students' career choice intentions, they were asked which career path they intended to pursue directly after their studies and five years after completion of their studies. Students could only select one answer for each question, from thirteen choices, grouped into four categories. The results of the four categories are summarised in Figure 2. 


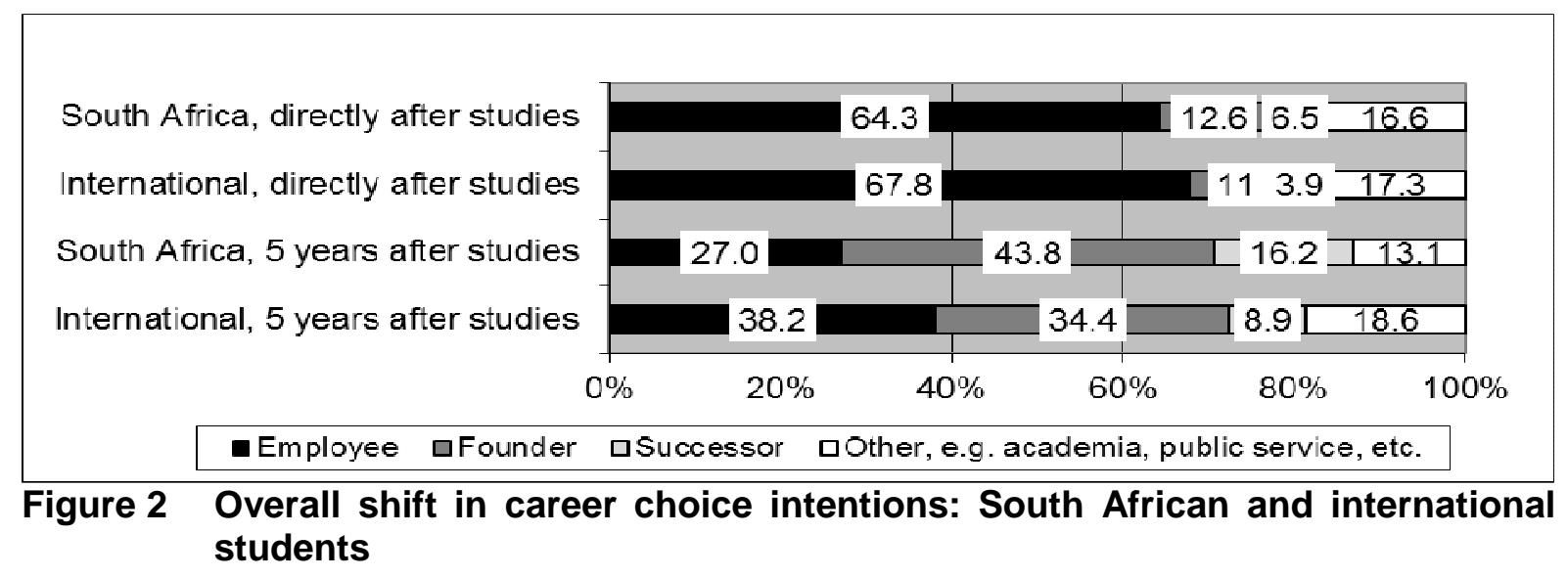

Figure 2 indicates a shift, for both samples, in favour of entrepreneurship as a career choice five years after graduation. The shift suggests that the majority of the participating students intended to gain experience in established firms before pursuing entrepreneurship as a longterm career option. In addition, slightly more South African students were interested in establishing their own businesses directly after graduation (12.6\% vs. $11.0 \%)$ and five years after graduation (43.8\% vs. $34.4 \%$ ) compared to the international sample. As shown in Table 6 , in comparison to the $2008 / 9$ survey, the intention to start a new business has decreased in both samples, especially in South Africa.

Table 6 Changes in career intentions over time

\begin{tabular}{|l|c|c|c|c|}
\hline & \multicolumn{2}{|c|}{ South African sample } & \multicolumn{2}{c|}{ International sample } \\
\hline $\begin{array}{c}\text { Intention to start a new } \\
\text { business }\end{array}$ & $\mathbf{2 0 1 1}$ & $\mathbf{2 0 0 8 / 9}$ & $\mathbf{2 0 1 1}$ & $\mathbf{2 0 0 8 / 9}$ \\
\hline Directly after graduation & $12.6 \%$ & $25.0 \%$ & $11.0 \%$ & $15.7 \%$ \\
\hline Five years after graduation & $43.8 \%$ & $61.3 \%$ & $34.4 \%$ & $42.2 \%$ \\
\hline
\end{tabular}

Since the publication of the 2008/9 survey, the global economic climate has changed considerably. SMMEs have been particularly hard hit by the global financial crisis, with most of the job losses in the global economy occurring in this sector (The impact of the global crisis on SME and entrepreneurship financing and policy responses 2009). Students might therefore have become more wary of entrepreneurship as career choice.

\section{THE ENTREPRENEURIAL BEHAVIOURS OF STUDENTS}

The GUESSS is based on the premise that entrepreneurial behaviour is preceded by entrepreneurial intentions. Entrepreneurial intentions are influenced by an individual's personal and family background, motives for becoming an entrepreneur, and exposure to entrepreneurship education. According to Farrington, Venter and Neethling (2012:19), the use of intentions models as a means of explaining entrepreneurial intentions have increased in entrepreneurship research in recent years. Most of these models are based on the work of Shapero and Sokol (1982) and Ajzen (1991).

Ajzen's (1991) Theory of Planned Behaviour suggests that the degree of intention is proportional to the probability of action; however the intention is preceded or influenced by a combination of three factors. It is the individual's attitude towards the intended action which refers to the self-image of the individual in performing the perceived behaviour, in this case being engaged in entrepreneurial activity. It is also the normative context of the individual which refers to the degree of influence the social environment of the individual has on influencing him or her to engage in entrepreneurship activity. Lastly, it includes the individual's perception of their ability to succeed in the intended role of being an 
entrepreneur which would invariably be influenced by past experience and their ability to overcome obstacles.

According to Shapero and Sokol's (1982) Entrepreneurial Events Model, entrepreneurship activity is triggered by externalities that constitute a major shift or unbalanced force in the environment within which the person finds him/herself. These externalities could be political or religious displacement, job dissatisfaction, ethnicity, family, friends, colleagues and even mentors. Externalities can have a negative or positive influence on the environment, however, negative externalities are found to have a larger influence on entrepreneurship activity.

To these ends, the activities of the students with intentions to found a business are investigated in the following section.

\section{Intentional founders}

Of the South African respondents, 70.6 per cent had intentions to establish an own company, while from the international sample, 42.1 per cent showed similar intentions. A section of the questionnaire was devoted to collect data on the activities of students who intended to found a business. Students were probed on the steps followed in setting up the business, the anticipated founding date, intended industry, founding idea, potential partners, capital required and perceived barriers to founding a business. The responses to these issues are reported below.

\section{Steps in setting up the business}

Intentional founders had to indicate which steps, ranging from non-activity and tentative steps, to the more concrete actions, such as purchasing equipment, they have taken towards setting up their own businesses. Students could select more than one step. The findings relating to this question are presented in Table 7.

Table 7 Steps taken towards setting up a business

\begin{tabular}{|c|c|c|c|c|}
\hline \multirow[t]{2}{*}{ Steps taken } & \multicolumn{2}{|c|}{$\begin{array}{c}\text { South African intentional } \\
\text { founders } \\
(\mathrm{N}=492)\end{array}$} & \multicolumn{2}{|c|}{$\begin{array}{c}\text { International intentional } \\
\text { founders } \\
(\mathrm{N}=39280) \\
\end{array}$} \\
\hline & $\mathbf{N}$ & $\%$ & $\mathbf{N}$ & $\%$ \\
\hline No steps taken & 105 & 21.3 & 10592 & 27.0 \\
\hline Thinking through initial business ideas & 334 & 67.9 & 25395 & 64.7 \\
\hline Developed a business plan & 89 & 18.1 & 7330 & 18.7 \\
\hline Identified a market opportunity & 233 & 47.4 & 13353 & 34.0 \\
\hline Looked for potential partners & 164 & 33.3 & 10862 & 27.7 \\
\hline Purchased equipment & 13 & 2.6 & 2152 & 5.5 \\
\hline Worked on product development & 46 & 9.3 & 3731 & 9.5 \\
\hline Discussed with potential customers & 67 & 13.6 & 5225 & 13.3 \\
\hline Requested funding from institutions & 8 & 1.6 & 1165 & 3.0 \\
\hline Decided on date of foundation & 18 & 3.7 & 1416 & 3.6 \\
\hline
\end{tabular}

Except for identification of a market opportunity and purchasing of equipment, it appeared that the steps taken towards setting up a business for the South African and international sample showed a relatively similar trend. Although students expressed a keen interest in entrepreneurship in the long term, the evidence did not show concretisation of their interest in the short term. However, the purchasing of equipment was the highest level of concrete steps towards setting up a business, and the South African sample $(2.6 \%)$ seemed to have not made the financial commitment to the degree that the international sample $(5.5 \%)$ had done. 


\section{Anticipated founding date}

Intentional founders were also asked to indicate the anticipated time (in years) that it would take until they actually established their own business. Only 3.4 per cent of the South African sample and 3.7 per cent of the international sample answered this question, indicating periods ranging from less than one year to more than ten years, comparative to a short-, medium- and long-term view. Barring the students with a short-term founding date, less than one year, this finding was indicative of the notion that the physical start-up of a business venture is often seen as a vague, futuristic action. This is in line with the previous finding of students first wanting to obtain relevant business experience before opting for the establishment of an own venture.

\section{Anticipated industry}

To better understand the industries the students were targeting, the students were asked in which industries they would establish their businesses. The South African students' responses in order of industry preference was firstly the finance industry, followed by advertising, marketing and design industries and then the hospitality, professional consulting, information technology (IT) and retail industries. The construction industry was viewed as the least attractive industry by prospective entrepreneurs. The international students primarily showed interest in the advertising, marketing and design, communications, IT, law, tax and consulting industries.

\section{Formulation of founding idea}

Idea generation can be attributed to various sources and has captivated researchers for decades (Lindsay \& Craig 2002:13; Howell \& Boies 2004:123; Barringer \& Ireland 2008:30). Respondents were asked concerning the sources of their founding ideas for starting a business. More than one source could be selected for the idea. The results are presented in Table 8.

Table 8 Source of founding idea

\begin{tabular}{|l|c|c|c|c|}
\hline \multirow{2}{*}{ Source } & \multicolumn{2}{c|}{$\begin{array}{c}\text { South African } \\
\text { intentional founders } \\
\text { (N = 492) }\end{array}$} & $\begin{array}{c}\text { International intentional } \\
\text { founders } \\
\text { (N=39 280) }\end{array}$ \\
\cline { 2 - 5 } & $\mathbf{N}$ & $\mathbf{N}$ & $\mathbf{N}$ & $\%$ \\
\hline Hobby or recreational pastime & 210 & 42.7 & 12223 & 31.1 \\
\hline University studies & 198 & 40.2 & 17805 & 45.3 \\
\hline Idea from self or fellow students & 151 & 30.7 & 11787 & 30.0 \\
\hline Family members & 144 & 29.3 & 7152 & 18.2 \\
\hline Academic, scientific or applied research & 78 & 15.9 & 4513 & 11.5 \\
\hline Current or former work activity & 71 & 14.4 & 10552 & 26.9 \\
\hline Friends outside university & 50 & 10.2 & 4325 & 11.0 \\
\hline
\end{tabular}

The main source of ideas for the South African respondents originated from their hobbies or recreational pastimes $(42.7 \%)$, followed by university studies $(40.2 \%)$ and for the international sample it is primarily from their university studies $(45.3 \%)$, followed by their hobbies or recreational pastimes $(31.1 \%)$. In both samples groups, friends outside the university made the lowest contribution to new business ideas.

\section{Anticipated partnering}

Intentional founders were asked if they planned to establish their business with any partners and if so, how many. The results are presented in Table 9. Most of the respondents in the two samples showed a preference for partnering with one or two partners. 
Table 9 Number of anticipated founding partners

\begin{tabular}{|l|r|r|r|r|}
\hline \multirow{2}{*}{ Number of partners } & \multicolumn{2}{|c|}{$\begin{array}{c}\text { South African } \\
\text { intentional founders }\end{array}$} & \multicolumn{2}{c|}{$\begin{array}{c}\text { International } \\
\text { intentional founders }\end{array}$} \\
\cline { 2 - 5 } & $\mathbf{N}$ & \multicolumn{1}{c|}{$\%$} & $\mathbf{N}$ & \multicolumn{1}{c|}{ \% } \\
\hline None & 156 & 31.7 & 13808 & 35.2 \\
\hline One partner & 173 & 35.2 & 15656 & 39.9 \\
\hline Two partners & 110 & 22.4 & 7038 & 17.9 \\
\hline Three partners & 29 & 5.9 & 1514 & 3.9 \\
\hline Four or more partners & 24 & 4.9 & 1264 & 3.2 \\
\hline Total & $\mathbf{4 9 2}$ & $\mathbf{1 0 0}$ & $\mathbf{3 9 2 8 0}$ & $\mathbf{1 0 0}$ \\
\hline
\end{tabular}

Intentional founders who preferred to start their business with one or more partners were asked to elaborate on where they planned to recruit these partners from. Multiple answers were permitted, and it was found that partnership with either university acquaintances or friends was preferred over family and spouses. Furthermore, intentional founders were asked concerning ownership. The majority of founders $(60 \%$ of the South African sample and $62.5 \%$ of the international sample) leaned towards staying in control of their own businesses.

Capital

Less than a third of the respondents (22.6\% of the South African sample and $27.9 \%$ of the international sample) had an idea of the amount and type of capital required to establish their businesses. This result was not surprising, considering the levels of demand for lectures and seminars on financing entrepreneurial ventures (see Table 3). Intentional founders were also asked concerning the source of their finances. Figure 3 represents the findings for sources of finance expressed as percentages.

Prize money from business competitions/idea contests etc.

Subsidies from foundations, trusts, government programs, etc.

Equity capital from external investors (e.g., business angels)

Capital (debt and equity) from family and friends

Bank loans

Own funds

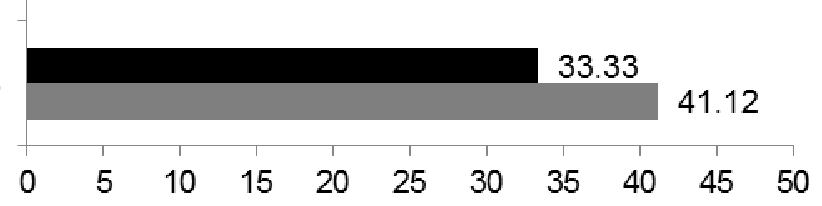

- South African $\quad$ International

\subsection{7}
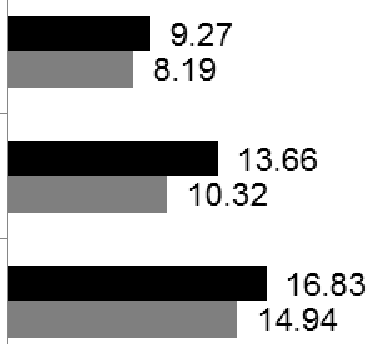
4.94

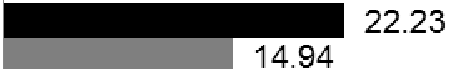

2.23

Figure 3: Planned sources of finance (in percentages)

(Intentional founders South African N = 492; Intentional founders international N = 39 280)

An analysis of Figure 3 suggests a strong preference for own funding followed by debt financing and preference shares. The identified order is in line with existing capital structure literature (Myers 1984:581; Fama \& French 2002:1). 
Perceived barriers to founding a business

The perceptions of the respondents on the barriers to founding a business were gauged on a seven-point Likert-scale with 1 representing 'not applicable at all' to 7 representing 'very applicable'. The perceived barriers to founding an own business are ranked in Table 10 from the highest to the lowest mean scores with reference to the South African sample.

Table 10 Perceived barriers to founding an own business

\begin{tabular}{|l|r|r|r|r|r|r|}
\hline \multirow{2}{*}{ Statement } & \multicolumn{3}{l}{ South African students } & \multicolumn{3}{l}{ International students } \\
\cline { 2 - 7 } & Valid N & Mean & SD & Valid N & Mean & SD \\
\hline Access to capital (debt and equity financing) & 488 & 5.10 & 1.61 & 38652 & 4.89 & 1.80 \\
\hline Bearing financial risk & 486 & 4.45 & 1.73 & 38501 & 4.42 & 1.77 \\
\hline General economic environment & 484 & 4.21 & 1.60 & 38520 & 4.15 & 1.75 \\
\hline Lack of contact to clients/customers & 489 & 3.98 & 1.73 & 38468 & 3.99 & 1.82 \\
\hline Having relevant technical know-how & 486 & 3.68 & 1.80 & 38419 & 3.54 & 1.86 \\
\hline High workload of an entrepreneur & 488 & 3.65 & 1.81 & 38406 & 3.37 & 1.86 \\
\hline State laws (rules and regulations) & 487 & 3.50 & 1.76 & 38511 & 3.89 & 1.83 \\
\hline Having the necessary skills and capabilities & 485 & 3.49 & 1.86 & 38467 & 3.47 & 1.87 \\
\hline Lack of the right business idea & 486 & 3.41 & 1.76 & 38476 & 3.40 & 1.93 \\
\hline
\end{tabular}

The three most highly rated perceived barriers to founding an own business are similar for the South African and the international samples, namely access to capital (debt and equity financing), bearing financial risk and general economic environment respectively. The South African findings are in line with those of Preisendörfer, Bitz and Bezuidenhout (2012:3) who found that the most significant barriers for the expansion of black entrepreneurship in South African townships are restricted financial and human capital resources. The lack of access to finance was also the major hindrance to promoting indigenous entrepreneurship in Australia (Shoebridge, A., Buultjens, J. \& Peterson, L-S. 2012:1). The ranking of the perceived barriers in Table 10 differs somewhat from that of the 2010 South African Global Entrepreneurship Monitor (GEM) where access to finance and financial support only ranks third behind inadequate and ineffective education and training and government policies (Herrington, Kew \& Kew 2010:31).

Attention now shifts to students who have already founded businesses of their own, i.e. active founders.

\section{Active founders}

As expected, a very small portion of the South African sample $(2.4 \%)$ comprised active founders. Although the sample was too small to determine trends in all dimensions probed, the data gathered still illuminated and confirmed some of the trends proposed by the intentional founders.

Most of the active founder respondents (58.8\%) founded businesses on their own. Consistent with the intentional founders' choices in terms of industry sectors, the highest percentage of respondents in both samples indicated doing business in the information technology and communications industry. 
With regard to sources of ideas, universities were perceived as important breeding grounds for new business ideas. Business ideas for both samples originated from self or fellow students, current or former work activities, university studies, family members, hobbies or recreational pastimes as well as friends outside university. The international sample also derived ideas from academic, science or applied research, which was not the case with the active founders from the South African sample.

The active founders were also asked whether they had any relevant experience before founding their business. Students in the international sample had more experience than their South African counterparts (of the South African sample $70.6 \%$ did not have relevant professional work experience before starting their own business whereas for the international sample it was $34.6 \%$ ).

\section{Sources of finance}

Figure 5 illustrates the sources of finance used to start an own business compared to the intended sources. Own funds were used to finance the active founders in more than 70 per cent of the cases in both samples, which is in agreement with existing literature (Barringer \& Ireland 2008:286). The share of equity in the majority of the cases for both samples was either 100 per cent or 50 per cent.

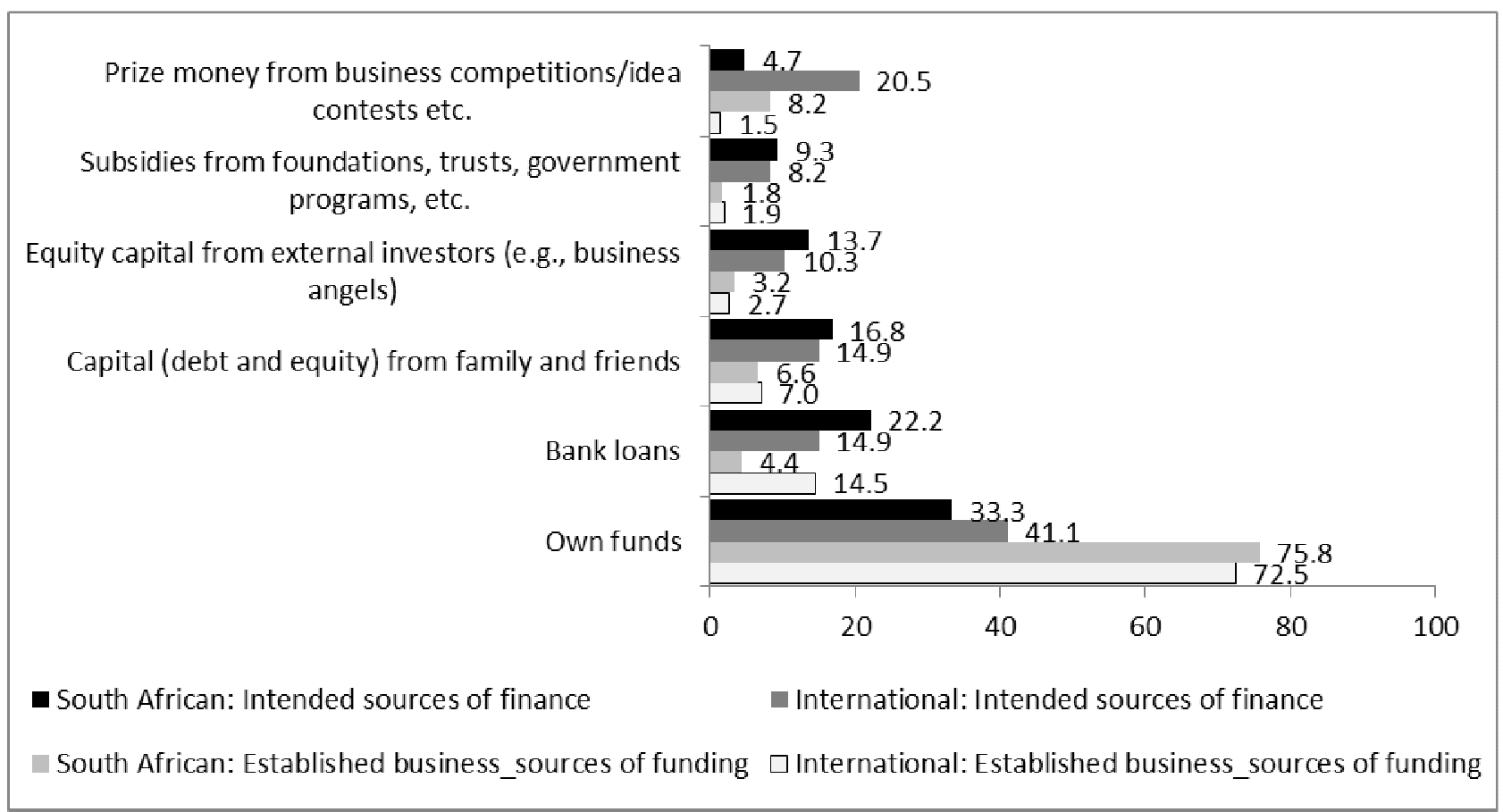

Figure 4 Comparison between intended and utilised sources of finance (in percentages) (Active founders: South Africa $\mathrm{N}=17$; international $\mathrm{N}=2324$ )

Number of employees and annual sales in established businesses (current and planned) Of the South African respondents, a quarter had no employees, a third employed one or two employees, and 40.2 per cent employed three to twenty-five employees. Almost a third of the South African respondents planned to employ at least 50 employees in five years' time. Of the international sample, 48.6 per cent had no employees.

Fourteen South African respondents provided information about their annual sales figures. Slightly more than 14 per cent made no sales in the previous year, just over 64 per cent generated sales of less than R2 million, the rest (almost 22\%) reached sales between R2 million and R12 million. More than half (57\%) planned to have sales over R12 million in five years' time. Surprisingly, one respondent did not plan to generate sales. This was 
possibly a non-profit organisation. An intention regarding business growth in the short to medium term was observed.

Business performance since establishment

The performance for the businesses that have been established by the South African and international samples is shown in Table 11, and is ranked from the highest to the lowest mean scores, based on the South African sample.

Table 11 Business performance since its establishment

\begin{tabular}{|c|c|c|c|c|c|c|c|c|c|c|c|c|c|}
\hline \multirow[t]{2}{*}{ Statement } & \multicolumn{3}{|c|}{ South African students } & \multicolumn{7}{|c|}{ Frequency distribution (\%) } & \multicolumn{3}{|c|}{$\begin{array}{l}\text { International } \\
\text { students }\end{array}$} \\
\hline & Valid N & Mean & SD & $\begin{array}{c}1 \\
\text { Worse }\end{array}$ & $\begin{array}{c}2 \\
\text { Pretty } \\
\text { bad }\end{array}$ & $\begin{array}{c}3 \\
\text { Rather } \\
\text { bad }\end{array}$ & $\begin{array}{c}4 \\
\text { Equal }\end{array}$ & $\begin{array}{c}5 \\
\text { Rather } \\
\text { good }\end{array}$ & $\begin{array}{c}6 \\
\text { Better }\end{array}$ & $\begin{array}{c}7 \\
\text { Best }\end{array}$ & $\begin{array}{l}\text { Valid } \\
\mathbf{N}\end{array}$ & Mean & SD \\
\hline $\begin{array}{l}\text { Development } \\
\text { of profit }\end{array}$ & 17 & 4.71 & 1.21 & 0.0 & 0.0 & 11.8 & 41.2 & 23.5 & 11.8 & 11.8 & 2258 & 4.37 & 1.64 \\
\hline $\begin{array}{l}\text { Development } \\
\text { of sales }\end{array}$ & 17 & 4.47 & 1.23 & 0.0 & 5.9 & 11.8 & 35.3 & 29.4 & 11.8 & 5.9 & 2272 & 4.38 & 1.67 \\
\hline $\begin{array}{l}\text { Development } \\
\text { of market } \\
\text { share }\end{array}$ & 17 & 4.35 & 1.58 & 0.0 & 17.6 & 11.8 & 23.5 & 17.6 & 23.5 & 5.9 & 2254 & 4.11 & 1.66 \\
\hline $\begin{array}{l}\text { Creation of } \\
\text { jobs }\end{array}$ & 17 & 3.35 & 1.50 & 17.6 & 5.9 & 23.5 & 35.3 & 11.8 & 5.9 & 0.0 & 2255 & 3.38 & 1.82 \\
\hline
\end{tabular}

The findings for both samples reveal that sales, market share and the creation of jobs developed as expected by the active founders. The development in market share also demonstrated a good performance by the South African sample.

\section{Foundation process}

The principles for the foundation processes for both samples are listed in Table 12, and are ranked from the highest to the lowest mean scores, based on the South African sample. The respondents' level of agreement with a number of founding principles was gauged by way of a seven-point Likert-scale.

Table 12 Foundation process principles

\begin{tabular}{|l|r|r|r|r|r|r|}
\hline \multicolumn{1}{|c|}{ Statement } & \multicolumn{3}{c|}{$\begin{array}{c}\text { South African } \\
\text { students }\end{array}$} & \multicolumn{3}{c|}{$\begin{array}{c}\text { International } \\
\text { students }\end{array}$} \\
\cline { 2 - 7 } & $\begin{array}{c}\text { Valid } \\
\text { N }\end{array}$ & Mean & SD & $\begin{array}{c}\text { Valid } \\
\text { N }\end{array}$ & Mean & SD \\
\hline $\begin{array}{l}\text { I was careful not to commit more resources } \\
\text { than I could afford to lose }\end{array}$ & 17 & 5.65 & 1.37 & 2245 & 5.04 & 1.89 \\
\hline $\begin{array}{l}\text { I allowed the business to evolve as } \\
\text { opportunities emerged }\end{array}$ & 17 & 5.53 & 1.07 & 2250 & 5.37 & 1.52 \\
\hline $\begin{array}{l}\text { I was flexible and took advantage of } \\
\text { opportunities as they arose }\end{array}$ & 17 & 5.41 & 0.80 & 2244 & 5.69 & 1.32 \\
\hline $\begin{array}{l}\text { I used a substantial number of agreements } \\
\text { with customers, suppliers and other } \\
\text { organisations and people to reduce the } \\
\text { amount of uncertainty. }\end{array}$ & 17 & 5.41 & 1.23 & 2251 & 4.42 & 1.89 \\
\hline $\begin{array}{l}\text { I adapted what I was doing to the } \\
\text { resources we had. }\end{array}$ & 17 & 5.35 & 1.10 & 2241 & 5.43 & 1.50 \\
\hline $\begin{array}{l}\text { I used pre-commitments from customers } \\
\text { and suppliers as often as possible. }\end{array}$ & 17 & 5.29 & 0.92 & 2247 & 4.42 & 1.98 \\
\hline $\begin{array}{l}\text { I analysed long-run opportunities and } \\
\text { selected what I thought would provide the }\end{array}$ & 17 & 5.24 & 1.39 & 2261 & 4.25 & 2.02 \\
\hline
\end{tabular}




\begin{tabular}{|l|r|r|r|r|r|r|}
\hline best returns. & & & & & & \\
\hline $\begin{array}{l}\text { I designed and planned business } \\
\text { strategies. }\end{array}$ & 17 & 5.06 & 1.64 & 2256 & 4.50 & 1.88 \\
\hline $\begin{array}{l}\text { I tried a number of different approaches } \\
\text { until I found a business model that worked. }\end{array}$ & 16 & 5.06 & 1.73 & 2246 & 3.48 & 2.04 \\
\hline $\begin{array}{l}\text { I avoided courses of action that restricted } \\
\text { our flexibility and adaptability. }\end{array}$ & 17 & 5.00 & 1.28 & 2250 & 4.93 & 1.64 \\
\hline $\begin{array}{l}\text { I organised and implemented control } \\
\text { processes to make sure we meet } \\
\text { objectives. }\end{array}$ & 17 & 5.00 & 1.32 & 2251 & 4.18 & 1.93 \\
\hline $\begin{array}{l}\text { The product/service that I now provide is } \\
\text { essentially the same as originally } \\
\text { conceptualised. }\end{array}$ & 17 & 5.00 & 1.32 & 2247 & 4.92 & 1.80 \\
\hline $\begin{array}{l}\text { I researched and selected target markets } \\
\text { and did meaningful competitive analysis. }\end{array}$ & 17 & 5.00 & 1.54 & 2256 & 4.28 & 1.96 \\
\hline $\begin{array}{l}\text { I was careful not to risk more money than I } \\
\text { was willing to lose with my initial idea. }\end{array}$ & 17 & 5.00 & 1.77 & 2241 & 4.94 & 1.92 \\
\hline $\begin{array}{l}\text { I was careful not to risk so much money } \\
\text { that the business would be in real trouble } \\
\text { financially if things did not work out. }\end{array}$ & 17 & 4.88 & 1.83 & 2248 & 5.08 & 1.90 \\
\hline $\begin{array}{l}\text { I experimented with different products } \\
\text { and/or business models. }\end{array}$ & 17 & 4.59 & 1.70 & 2244 & 3.86 & 2.04 \\
\hline $\begin{array}{l}\text { I designed and planned production and } \\
\text { marketing efforts. }\end{array}$ & 17 & 4.41 & 1.46 & 2243 & 4.26 & 1.94 \\
\hline $\begin{array}{l}\text { The product/service that I now provide is } \\
\text { substantially different than I first imagined. }\end{array}$ & 17 & 4.29 & 1.96 & 2252 & 3.23 & 2.10 \\
\hline
\end{tabular}

It is evident from Table 12 that similar principles are dominant across the two samples. Active founders preferred not to over-commit their resources and remained flexible enough to integrate new ideas into their business, and turn these ideas into opportunities.

\section{South Africa's GUESSS entrepreneurial index value}

The GUESSS entrepreneurial index value provides an indication of entrepreneurial power which is determined by comparing the extent to which students thought of founding a business to the extent to which they have already become active entrepreneurs. The findings revealed an entrepreneurial index value of 25.13 for the South African student sample. The value of the entrepreneurial index value for the overall sample is 27.22. The relative value reinforces the gap between intentions and actions among South African students noted earlier in this article. Polish students reported the highest entrepreneurial index value (68.25) and Tunisian students reported the lowest entrepreneurial index value (16.00).

\section{SUMMARY, CONCLUSIONS AND RECOMMENDATIONS}

This article reported on the entrepreneurial intention and behaviour of South African university students. Comparisons were made between a South African sample and an international sample of university students. The profiles of the South African and international samples were relatively similar in terms of age, gender and study level. Students in the international sample were, however, slightly older than their South African counterparts and were more likely to be enrolled for a postgraduate qualification.

In the three categories of entrepreneurship offerings evaluated, namely lectures and seminars, workshops and coaching opportunities, and provision of resources, South African 
students were more aware of entrepreneurship offerings at their universities and utilised more of the offerings than the international sample and also expressed higher levels of satisfaction. Both groups of students were generally satisfied with the available offerings, but demanded additional practical activities and resources, such as seed funding and financial support.

The university context had a positive influence on South African students' entrepreneurial intentions and behaviours. In particular contact with likeminded peers and mentors were regarded as important in generating business ideas and understanding the entrepreneurial process.

Existing entrepreneurship literature suggests that the level of entrepreneurship in South Africa is low and generally of a poor quality. South Africa ranks relatively high in the 20102011 global competitiveness report in terms of the standard of scientific research institutions ( $29^{\text {th }}$ out of 139 countries) (Schwab 2011:39). The challenge lies in the fact that only 15 per cent of South Africans have access to tertiary education, placing South Africa in $99^{\text {th }}$ position in the global ranking. Access to tertiary education should be addressed to unlock the country's innovation potential, and universities in South Africa should increase the number of postgraduate students.

Although the intention to start a new business had decreased in South Africa compared to the 2008/9 survey, in general, South African students were more interested in establishing their own businesses than the international sample. Both groups of students were more inclined to start their own ventures after gaining some industry experience and establishing support networks.

The majority of South African students (70.6\%) viewed themselves as intentional founders, as opposed to 42.1 per cent of students in the international sample. A clear pattern of passivity was observed among students in both the samples in that very few realised their intentions to start their own businesses with goal-driven actions.

A possible solution could be to assist students in taking small steps towards their goal with an easy, achievable start. Therefore, a number of smaller actions could help potential entrepreneurs to turn their thoughts into actions, and their dreams into reality. A stronger emphasis should also be placed on increasing pro-activeness and the value of a business plan as a roadmap - not only in the start-up phases, but also in subsequent phases. The researchers are of the opinion that, unless entrepreneurs are empowered with the necessary legislative support and increased skills, easier access to funding may even increase the cost of small business failure.

Notably, the international sample viewed previous work experience as a major source of business ideas and learning opportunities, which was not the case with the South African sample. This might be partly attributed to the fact that there is no formal internship requirement as part of the South African university curriculum. South African universities could include internships in their entrepreneurship offerings.

Universities need to assess the level of students' awareness, utilisation and satisfaction regarding entrepreneurship offerings. Furthermore they should investigate the demand for particular activities to boost entrepreneurial orientation, clarify the entrepreneurship process and enhance business management skills. The marketing of entrepreneurial offerings should be more strategically focussed. Entrepreneurship offerings need to be marketed with specific levels of audiences in mind. The first level refers to those that need to be made aware or sensitised, followed by those that are sensitised and need to be encouraged to act, while the third level would be those who have acted and need support. 
This article contributes to a better understanding of entrepreneurship offerings at South African universities and suggests how universities could strategise and formulate more streamlined entrepreneurship education strategies. More specifically, it is recommended that universities firstly adopt a comprehensive, three-phased approach: sensitise, act, support. In addition, they should continually review and realign entrepreneurship offerings targeting specific areas of business requirements, for example, dealing with the financial aspects of new venture creation, prepare students to gain immediate access to the labour market, and lastly enhance network development with relevant stakeholders.

Research-driven approaches are required for a better understanding of how to develop entrepreneurship. Africa suffers from a lack of comprehensive entrepreneurship research and should develop a more balanced and holistic perspective of entrepreneurship research, (Kiggundu 2002:241). Kiggundu suggests that more comprehensive entrepreneurship research is required and that African researchers include the entrepreneur and not only the firm and external environment in their research. Kiggundu further postulates entrepreneurship research be scaled towards an integral part of useable mainstream knowledge instead of receiving traditional 'step-child' status.

Access to capital (in this study, referred to as the perceived barrier to obtaining start-up capital) was viewed as a major stumbling block in the initial phases of establishing a business. Although the South African government has increased its support to new businesses, communication around these opportunities is not conveyed in a consistent and clear manner. Furthermore, it seems that the message does not reach the intended target audience. Government should employ more focussed strategies of communicating the infrastructure of their support. They, government, should thus invest in more effective, structured links with universities to change these perceptions and to reverse the apparent lack of concrete entrepreneurial actions among students.

\section{ACKNOWLEDGEMENTS}

The authors sincerely thank Pearson Education Southern Africa and the Braxton Group for financial support of this research.

\section{REFERENCES}

Ajzen, I. 1991. The theory of planned behavior. Organizational Behavior and Human Decision Processes, 50(2):179-211.

Autio, E. 2005. Global Entrepreneurship Monitor: 2005 Report on high expectation entrepreneurship. London School of Business, Mazars \& Babson. [Online]. Available from: http://www.gemconsortium.org/docs/download/268 [Accessed 2012-03-30].

Barringer, B.R. \& Ireland, R.D. 2008. Entrepreneurship: successfully launching new ventures. $2^{\text {nd }}$ ed. New Jersey: Pearson.

Fama, E.F. \& French, K.R. 2002. Testing trade-off and pecking predictions about dividends and debt. Review of Financial Studies, 5(1):1-33.

Farrington, S.M., Venter, D.J.L. \& Neethling, A. 2012. Entrepreneurial attributes and intentions: perceptions of South African business science students. Management Dynamics, 21(3):17-33. 
Farrrington, S.M., Gray, B. \& Sharp, G. 2011. Perceptions of an entrepreneurial career: Do small business owners and university students concur? Management Dynamics, 20(2):2-17.

Frese, M. \& De Kruif, M. 2000. Psychological success factors of entrepreneurship in Africa: A selective literature review, in Frese, M. (ed.). 2000. Success and failure of microbusiness owners in Africa: A psychological approach; Westport: Quorum.

Herrington, M., Kewe, J. \& Kew, P. 2010. 2010 Global Entrepreneurship Monitor. Cape Town: UCT Centre for Innovation and Entrepreneurship.

Howell, J.M. \& Boies, K. 2004. Champions of technological innovation: The influence of contextual knowledge, role orientation, idea generation, and idea promotion on champion emergence. The Leadership Quarterly, 15(1):123-143.

Kiggundu, M.N. 2002. Entrepreneurs and entrepreneurship in Africa: What is known and what needs to be done. Journal of Developmental Entrepreneurship, 7(3):239-258.

Lindsay, N.J. \& Craig, J.B. 2002. A framework for understanding opportunity recognition entrepreneurs versus private equity financiers. The Journal of Private Equity, 6(1):1324.

Myers, S. C. 1984. The Capital Structure Puzzle. Journal of Finance. July, 39(3):575-92.

Preisendörfer, P., Bitz, A. \& Bezuidenhout, F.J. 2012. Business Start-ups and Their Prospects of Success in South African Townships. South African Review of Sociology, 43(3):3-23.

Radipere, S. 2012. South African university entrepreneurship education. African Journal of Business Management, 6(44):11015-11022.

Republic of South Africa. Department of Science and Technology, 2007. Innovation towards a knowledge-based economy: Ten-year plan for South Africa (2008-2018) [Online]. Available from:

http://www.esastap.org.za/download/sa_ten_year_innovation_plan.pdf [Accessed: 2012-04-04].

Scheepers, M.J., Solomon, G. \& De Vries, A. 2009. Global university entrepreneurial spirit students' survey: South African report. Entrepreneurial intentions and behaviour of South African university students. University of Stellenbosch. [Online] Available from: [http://www.guesssurvey.org/e_publication_nat.html [Accessed: 2011-01-17].

Schwab, K. (ed.). 2011. The global competitiveness report 2010-2011. World Economic Forum. [Online]. Available from:

http://www3.weforum.org/docs/WEF_GlobalCompetitivenessReport_2010-11.pdf [Accessed: 2011-08-05].

Shapero, A. \& Sokol, L. 1982. The social dimensions of entrepreneurship. In Kent, C.A., Sexton, D.L. \& Vesper, K.H. (eds.). 1982. Encyclopaedia of entrepreneurship. Englewood Cliffs: Prentice Hall.

Shoebridge, A., Buultjens, J. \& Peterson, L-S. 2012. Indigenous entrepreneurship in Northern NSW, Australia. Journal of Developmental Entrepreneurship, 17(3):1-31.

The impact of the global crisis on SME and entrepreneurship financing and policy responses. 2009. Organisation for Economic Co-operation and Development, 23 June, [Online]. Available from: http://www.oecd.org/dataoecd/40/34/43183090.pdf [Accessed 2011-07-01].

The New Growth Path. 2011. South African government information. [Online]. Available from: http://www.info.gov.za/aboutsa/economy.htm [Accessed: 2011-04-01]. 